\title{
Colonial Legacies and the Struggle for Social Membership in a National Community: The 1946 People's Uprisings in Korea
}

\author{
JIN-YEON KANG*
}

\begin{abstract}
The historical experience of colonialism exerts a profound influence upon emergent postcolonial societies. Yet colonial legacies are not passed on in precisely the same way; rather, they are contingent on particular historical processes. In the case of Korea, Japanese colonialism gave way to a brief liberation phase that was followed by another foreign occupation (the U.S. in the south and the U.S.S.R. in the north) during which efforts were made to rebuild the political community. Focusing on the 1946 people's uprisings, the largest popular social movement during the U.S. occupation period, as a pivotal historical event, this article examines why the primary target of the uprisings was not the foreign military government but fellow Koreans, especially police officers, bureaucrats, and wealthy landlords, thereby revealing how Japanese colonial rule influenced the movement's choice of targets as well as its eventual failure. Through this historical analysis, I demonstrate that internal conflicts among Koreans, which were created and rearticulated through Japanese colonial rule, became critical sources of social and political struggles under the American occupation, the important consequence of which lies in the creation of a pattern of internal exclusion that characterized South Korea's post-war political trajectory.
\end{abstract}

$* * * * *$

On my way from work, I saw a lot of stuff piled in the street and people surrounding it. It was a high-ranking government employee's house, who'd lost favor with the people during the Japanese colonial period. They searched his house and found a lot of rice, sugar, and cotton fabric. This kind of stuff was really precious back then. People didn't take the stuff for themselves but put it in the street and shouted 'see this, now people are poorly clothed and suffering from hunger, and this son of bitch is living well against the people.' They cursed him and shouted he should be beaten to death.

On October 1, 1946, Taegu, a city in the North Kyŏngsang Province in Korea, became a center of protest, where women and children went to the city hall to demand rice, and sympathetic union workers and students gathered at the railroad station. As people took over the police station, attacks against policemen and government officials emerged, and martial law was proclaimed. The statement quoted above (Kang interview with author, May 7, 2008)

* Jin-Yeon Kang, who recently completed her Ph.D. in Sociology at the University of Michigan, is teaching at Yonsei University in Korea. 
describes an incident that took place in the evening of October 2 in Taegu, and testifies to how people expressed their collective grievances against government officials who served the Japanese during the colonial era and then the U.S. for the occupation period. After the political upheaval in the Kyŏngsang provinces, uprisings took place sporadically in other provinces as well until mid-December.

The uprisings took a surprising direction given the nearly four decades of oppressive Japanese colonial rule in Korea (1910August 1945), which was followed by a brief liberation phase (August-September 1945) before the American occupation period (September 1945-1948). Having thrown off one foreign oppressor (Japan) only to be occupied by another (U.S.), the uprisings in 1946 did not target the American occupiers but rather fellow Koreans, especially police officers, bureaucrats, and wealthy landlords. Why was the primary target of the uprisings not the foreign military government but other Koreans? And, what does this suggest about the impact of Japanese colonialism on the movement's choice of targets as well as its eventual failure?

\section{Historical Context}

Korea was under Japanese colonial rule after it became a protectorate in 1905 and was formally annexed to Japan in 1910 until the Japanese defeat in World War II terminated the prolonged colonial rule in 1945. The liberation from oppressive colonial domination was immediately followed by the widespread development of various political organizations and voluntary social associations both at the local and national levels, reflecting and accelerating popular political participation. When two occupation forces subsequently entered Korea (the U.S. in the south and the Soviet Union in the north), however, efforts to reconstruct an independent national community had to face yet another form of foreign intervention by these external powers.

To the extent that terminating the coercive Japanese colonial rule intensified political and social aspirations for an independent state, and that the existence of the American Military Government (hereafter AMG) could impede the establishment of a sovereign nationstate, one might have expected the emergence of a national movement against the AMG. Surprisingly, however, no major national movements arose against the military rule. Although the AMG increased economic, political, and ideological tensions through a series of institutional changes, American military rule itself never became a primary target for popular struggles throughout the occupation period. In fact, social movements through which people directly attacked the military government comprised only 
about two percent of all social movements during the occupation period (Yi 1988: 231). Instead, Koreans tended to engage in violent collective actions against their fellow Koreans. People who once mobilized a nation-wide social movement in order to secure their national community from an external threat in the pre-colonial period and who resisted the oppressive colonial domination during the Japanese colonial period struggled against each other under the U.S. military occupation. Why?

It should be noted that Japanese colonial rule and the American occupation had significantly different historical contexts, and the ways in which they were viewed by the general public were, therefore, contrasting. While Japan was perceived as an illegitimate appropriator of an existing national community, resulting in strong resistance to its colonial rule even before its official launch in Korea, the U.S. occupation was enthusiastically accepted by most people including leftist activists precisely because it brought about political independence from Japanese colonial domination. For the Korean people, Japan appeared as an oppressor, whereas the U.S. was seen as a liberator, at least in the early occupation period.

This does not mean, however, that the general public continued to hold these positive attitudes toward the U.S. throughout the occupation period. What Koreans ultimately wanted from the U.S. was its assistance for rebuilding an independent nation-state, not another foreign rule. When the AMG announced itself as the only legitimate government, attempted to crush popular social and political organizations, and significantly exacerbated existing poor economic conditions, people came to perceive that "the liberators had become the oppressors" (Meade 1951: 62). Under these circumstances, it is understandable that strong acceptance could be converted into even stronger resistance against the AMG. Yet, the historical record is more complex and points instead to the intensification of the economic, political, and ideological struggles that divided the Korean people and fueled the opposition to their new "oppressors." The intensification of internal conflicts among Korean people under the AMG, then, needs to be explained rather than taken for granted.

Through analyzing the causes and consequences of the 1946 people's uprisings, ${ }^{1}$ this article examines why the primary target of the uprisings was not the foreign military government but rather other Koreans, and how the historical experience of Japanese colonial rule influenced the movement's choice of targets as well as its eventual failure. To this end, it focuses on the ways in which social boundaries among Korean people, which were redrawn through Japanese colonialism, played a crucial role in shaping a particular political trajectory in the liberation and occupation periods. In 
doing so, it aims to illuminate the effects of colonial legacies upon the reconstruction of the postcolonial community in South Korea.

\section{Colonial Legacies in the Process of Postcolonial State Formation}

As social scientists become more interested in colonialism, scholarly attention has been directed to the study of colonial legacies in postcolonial societies, with a particular focus on how the establishment of the colonial state and different forms of colonial rule left imprints upon political changes and state formation in postcolonial societies (e.g. Davidson 1992; Lange 2003, 2004; Mamdani 1996, 2003; Migdal 1988; Young 1994). One critical issue in (post) colonial studies is related to how different methods of colonial domination-in the form of direct or indirect rule-promoted particular forms of political change during postcolonial periods. Among others, Matthew Lange (2004: 906-08) argues that while the colonial state under direct rule tends to base its political domination upon a centralized administrative structure, thus promoting the rule of law, indirect rule consolidates the institutional and substantial power of chiefs as local intermediaries between the colonial administration and indigenous people, hence generating the tendency for despotism. These contrasting institutional legacies can be seen, for example, by comparing political changes in postcolonial India and Africa. Through the British colonial rule, India developed popular political culture as well as the infrastructural power of the state and consequently followed a democratic trajectory (Young 1994: 272-75; see Kohli 1990). In contrast, more coercive and extractive colonial rules in Africa gave rise to clientelism and tribalism that largely hindered political participation of the masses in postcolonial Africa (Davidson 1992; Mamdani 1996, 2003; Young 1994).

Mahmood Mamdani (1996) further elaborates the political legacy of indirect rule in the context of colonial and postcolonial Africa. Mamdani shows how the British and French imperial powers utilized the native authorities in the local state for effective colonial rule and generated "decentralized despotism" by providing the chiefdom with omnipotent power encompassing the judicial, legislative, executive, and administrative realms. Characterizing the colonial state as a "bifurcated state," Mamdani stresses that colonial rule produced a civic-communitarian division through which white settlers and a few Africans had been endowed with freedom and rights as citizens, while most Africans remained tribal subjects in the realm of rural communities. The gist of Mamdani's argument is that indirect rule implanted by the Western imperial powers in 
Africa consolidated the political power of tribal authorities, which is chiefly responsible for the development of ethnic conflicts and authoritarianism in the postcolonial period. Thus Mamdani (1996: 25) ultimately claims that the most important institutional legacy of colonial rule in Africa lies in the continent's inherited impediments to democratization.

Mamdani's work has enhanced our understanding of colonial legacy by illuminating the historical continuity between institutional political settings in the colonial period and political structures in postcolonial Africa. Yet, the way in which colonial legacies influence postcolonial politics remains contested. Frederick Cooper (2005: 18, 51-52), for example, criticizes Mamdani for ignoring the pivotal role of sequential processes in the political changes in postcolonial Africa. The problem of Mamdani's account, Cooper claims, lies in the fact that it makes a direct causal connection between forms of colonial rule during the 1920s and 1930s, on the one hand, and the postcolonial era of the 1980s and 1990s, on the other, while neglecting important political developments in the intervening period. To fill this gap, Cooper underscores the existence of effective mobilization of Africans for making claims to citizenship in the late 1940s and 1950s. Examining labor movements in the post-war period in French Africa, he shows how the Africans appropriated the languages of equality, citizenship, and claims-making within the imperial system, which in turn propelled the ousting of French colonial power and the opening of sources of political conflicts in the postcolonial era. Thus Cooper demonstrates that "the process of decolonization, not just the heritage of colonialism, shaped the patterns of postcolonial politics" (2005: 230, emphasis in original).

As the debate over Mamdani's work clearly shows, Mamdani and Cooper have developed contrasting, seemingly irreconcilable arguments about the politics of postcolonial Africa. The fact that they have different foci, however, does not necessarily mean that we need to choose one argument over the other. Rather, it is necessary to integrate both points of view to the extent that the reproduction of the colonial legacy itself is a product of political processes in postcolonial periods. It might be possible to combine Mamdani's and Cooper's arguments by explaining why and how institutional and political structures that were formed in a colonial situation remained largely intact in spite of the existence of popular efforts to democratize politics during postcolonial periods. In this regard, a more "process-centered" approach (Migdal 2001) is necessary for elucidating historical continuities or discontinuities from colonial to postcolonial periods.

Focusing on the largely neglected case of Japanese colonialism and its legacies in postcolonial politics in Korea, this article aims to 
develop a process-centered approach in order to show why and how colonial state structure was revived through the process of popular struggles. To this end, it advances two theoretical arguments. First, it highlights the pivotal role in postcolonial politics of internal conflicts that were created and reformulated among indigenous people through colonial rule. One theoretical problem in colonial studies stems from the widely accepted conceptual dichotomies of colonizer vs. colonized, civilized vs. primitive, and imperial citizen vs. colonial subject. As scholars have noted (Stoler and Cooper 1997; Prakash 1995; Young 1995), this binary conceptual distinction, especially between colonizer and colonized, is problematic rather than constructive. Certainly, the imposition of colonial rule tends to promote confrontation between the colonial power and colonized people, most notably in the form of anti-colonial nationalist movements. Yet, it is questionable to assume that indigenous people maintain the essential characteristics of their own collectivity throughout a colonial period without any changes (Goswami 2004: 24-25). And, underlying this assumption is the dominant view that colonized people share and reproduce the same identity and a unitary collective form. By exclusively focusing on differences, therefore, the dichotomy between colonizer and colonized seems to homogenize both groups. In doing so, it obscures the fact that various social groups within the indigenous people respond to and interact with the colonial power in significantly different ways (see Isaacman and Isaacman 1977). ${ }^{2}$ To the extent that many postcolonial societies experienced internal political and social conflict during the process of postcolonial state-building, it is important to consider how various social groups interacted differently with colonial powers, and how this in turn led to the development of contentious relationships among indigenous people.

The problem with focusing on the difference between colonizer and colonized is clearly revealed in the case of Korea. The puzzling situation in Korea under American occupation can be seen through the existence of intensive and continuous internal struggles. As the distinction between colonizer and colonized implies, if the Korean people had maintained the same collective interests and identity throughout the Japanese colonial period, they would have engaged in national integration, whether against or with the help of the $\mathrm{AMG}$, to achieve the national goal of an independent sovereign nation-state. The fact that political disputes among Koreans in the aftermath of Japanese colonial rule were often about the meaning of "collaboration" with the Japanese, however, indicates that a major source of internal conflicts stemmed from relationships with the Japanese colonial power. This suggests that the historical experience of Japanese colonialism drew boundaries not only between 
colonizer and colonized but also among the colonized people themselves. Therefore, it is critical to examine why and how internal boundaries among the Korean people, which were reformulated with the mediation of the colonial state, played an important role in the process of postcolonial state formation.

In addition to taking internal boundaries more seriously, this analysis offers a second theoretical contribution by advancing a process-centered view of postcolonial state formation as it impacts the reconstruction of political community. The academic literature in (post) colonial studies has largely focused on how the institutional arrangements and state apparatuses of the postcolonial period resemble those of the colonial era. One of the fundamental problems in postcolonial periods, however, is that the state form, which is embedded in a colonial structure, clashes with a community form that is based on cultural identity. As a result, the sources of political disorder in the process of postcolonial state formation stem not only from political hegemony or economic interest, but also from conflicts among various social groups aspiring to different types of political community. In this regard, as Partha Chatterjee (1993) argues, we need to consider political community and the state together in order to understand how they are mutually interconnected with each other. If we approach the postcolonial state both as an institutionalized form of government and as a political community, it becomes possible to explain the historical continuity between colonial and postcolonial periods with respect to cultural changes as well as institutional structures.

Like many other postcolonial societies, Korea saw a revival of a colonial state apparatus, especially a coercive police force, through the process of postcolonial state formation, although one of the strongest popular demands for reconstructing postcolonial society was the abolishment of colonial legacies. As we will see later, the resemblance of the colonial and postcolonial state forms resulted from the process of popular struggles in which people attacked fellow Koreans, particularly those who served the Japanese during the colonial period and were perceived as pro-Japanese collaborators. In a reaction to popular social movements, centralized and coercive state power was reorganized in a stronger form. This demonstrates that various social groups pursued their rights through different types of political community, and national identity and community membership themselves became a crucial source of internal conflicts. To better understand the process of postcolonial state formation, therefore, it is necessary to consider not merely institutional reproduction but perhaps more importantly the role of relational changes in social boundaries and identities in reconstructing the political community of postcolonial societies. 


\section{Why Korea?}

This article develops a case study of colonial and postcolonial Korea, which provides important theoretical insights for the following reasons. First, the investigation of Korean history elucidates the impact of colonialism upon a national community. Compared to other pre-colonial societies, Korea maintained a culturally homogeneous society before Japanese colonial rule (Duncan 1998; see Em 1999). Indeed, the Chosŏn dynasty (1392-1910) exhibited characteristics of what Anthony Smith (1987) calls an "ethnic community," such as a collective name, common myth of descent, shared history, distinctive culture, association with a specific territory, and sense of solidarity. ${ }^{3}$ The demand for national independence through the social movements in the pre-colonial era (e.g. Tonghak Peasant Movement in 1894) and colonial period (e.g. March First Movement in 1919) could be evidence of a national community and a sense of solidarity. In fact, cultural and ethnic homogeneity differentiates Korea not only from Western colonies but also from Taiwan, another Japanese colony. Thus the Korean case shows more clearly the effects of colonialism upon an already existing national community. ${ }^{4}$

In addition, a case study of Korea can expand the scope of colonial and postcolonial studies. While making significant theoretical contributions by uncovering histories of non-Western societies and the reciprocal relationship between imperial and colonial societies, initial studies tended to focus on histories of Western colonies. This led to a shift in theorizing based on the experiences of Western European countries to those of their "Others" in (post) colonial studies. Given the fact that Japan was a non-Western colonial power, Japanese colonialism was generally considered as an "anomaly" (Peattie 1984: 6-15) and, consequently, histories of Japanese colonies such as Korea was doubly underrepresented. If we consider that colonial rules by Western countries are divergent, not uniform, and thus there is no essential characteristic of Western colonial domination, then, Japanese colonialism can be seen as one of the various forms of colonial domination, rather than as an exceptional case. In this vein, it would be more constructive to examine colonial practice in its particular historical context and to compare similarities and differences among diverse practices of colonial rule.

Moreover, as the case of Korea demonstrates, the distinction between Western and non-Western colonialism is often blurred. After all, Korea was first colonized by Japan, a non-Western power, and after the brief liberation phase, the southern part of Korea became occupied by the U.S., a Western power. To be sure, 
Japanese colonialism had some distinctive temporal and spatial characteristics that are chiefly responsible for the particular traits of Japanese rule, such as method of rule, institutional arrangements, and colonial practices (Cumings 1984: 482). At the same time, however, the U.S. occupation played a significant role in shaping the structure of the subsequent postcolonial society. This suggests that neither Japanese colonialism nor the U.S. occupation alone can provide an adequate account of postcolonial politics in South Korea; rather, it is the sequence of both super-imposed foreign regimes that must be at the center of an analysis of postcolonial politics. By exploring how this temporal sequence of colonial rule and military occupation shaped postcolonial politics, we can extend the spatial and sequential scope of existing studies, and construct a preliminary foundation for comparative studies of colonialism and postcolonialism.

To this end, this article examines the 1946 uprisings with particular attention to the creation and intensification of internal conflicts among Koreans through the Japanese colonial era into the American occupation period. Among the many studies of the 1946 uprisings (Chŏng 1988; Cumings 1981; Kim 1984; Kim 1998; Shin 1994; Sim 1991), Bruce Cumings (1981) provides one of the most thorough historical accounts of the mobilization and of the American occupation period in general. Against the AMG's allegation of the communist influence of the movement, he highlights the voluntary and spontaneous characteristic of the uprisings and claims that the movement arose from below with the help of grassroots associations, especially the people's committees in local regions. Some scholars, however, direct attention to the active involvement of leftist activists in the movement and contend that the uprisings should be understood within the historical context of political and ideological conflicts. From this perspective, the uprisings were the product of the prolonged contentious relationship between leftists, particularly the Korean Communist Party on the one hand, and rightists and the AMG on the other (Kim 1984; Sim 1991). Integrating these different approaches, others argue that the uprisings were a result of a partial combination of peasants' economic problems and leftists' political interests (Kim 1998).

There is no doubt that these studies have contributed significantly to our understanding of the 1946 uprisings. With attention to the historical details, they have uncovered the actual process, multiple characteristics, and the significance of the movement in its own historical context. In spite of this rich literature, however, a central question still remains: Why was the target of the movement not the AMG but fellow Koreans? That people mainly attacked fellow Koreans is especially puzzling when we consider the active 
role of the AMG in exacerbating the economic and political situation during the occupation period. Furthermore, considering the intensive casualties caused by the uprisings, it is surprising that not a single American official was attacked throughout the movement. ${ }^{5}$ An American eyewitness indeed reported that "it was amazing to recall again that despite our active involvement, no harm had come to a single American. [. . .] They were merely settling their scores with the men and forces which oppressed them under our rule, as they did under the Japanese" (Gayn 1948: 388-89). To solve this empirical puzzle, the following sections explore why and how internal boundaries among Koreans that were produced and rearticulated during the Japanese colonial period became reformulated and intensified through the liberation phase and the occupation period.

\section{Redefining Social Membership in the National Community in the Liberation Phase}

Since Korea became a Japanese protectorate in 1905, it had been under Japanese colonial rule for four decades. Although decolonization resulted from the Japanese defeat in World War II, not from an indigenous anti-colonial movement, the coercive colonial rule led to the development of strong anti-Japanese sentiment among Koreans. Thus the most important task in the aftermath of Japanese colonial domination in Korea was to reconstruct an independent nation-state by abolishing colonial legacies. To achieve this goal, various political organizations and social associations emerged at the local as well as national level. In fact, on August 15, 1945, the day that Japan's surrender to the Allied Forces and the termination of Japanese colonialism was officially announced, the Committee for the Preparation of Korean Independence (Chosŏn kŏn'guk chunbi wiwŏnhoe, hereafter CPKI) was formed at the national level. ${ }^{6}$

At the center of CPKI were people from various political organizations, including the Korean Independence League (Chosŏn kŏn'guk tongmeang), Korean Communist Party (Chosŏn kongsandang), and New Korea Society (Sin'ganhoe), all of which played important roles in anti-colonial movements during the colonial period (Hong 1985: 72-91; Sŏ 1991: 195-215). Despite the lack of popular participation in its initial formation, the CPKI was able to gain the legitimate political status of a national organization primarily due to the fact that it consisted of anti-colonial activists, including nationalists and socialists, with the exception of some rightists who refused to participate in the organization. Indeed, one of the first actions of the CPKI was to release political offenders who 
were arrested by the Japanese. Due to strongly persisting antagonism against Japanese colonialism in the liberation context, personal experiences of participation in anti-colonial movements became more or less equated with proof of being a genuine patriot (see Ch'oe 1987: 80-81).

The creation of the CPKI was immediately followed by the establishment of local branches. By the end of August, the CPKI had 145 branches throughout all thirteen provinces in Korea (Minjujuŭi minjok chŏnsŏn, hereafter Minjŏn 1946: 81). When the CPKI was succeeded by the formation of the Korean People's Republic (Chosŏn inmin konghwaguk, hereafter KPR) on September 6, 1945, most CPKI branches were replaced by people's committees (inmin wiwonhoe) down to the village level (Cumings 1981: 270). The common activities of people's committees included organizing various social groups, such as youth, peasants, and workers; maintaining public order; and taking over and controlling lands, factories, and property owned by Japanese nationals and the Government-General of Korea. For peasants and workers, it was perceived as their right to regain access to land and property, which had been confiscated and exploited during the Japanese colonial period, and to participate in the political process in the context of liberation.

The characteristics and political orientation of the CPKI and its successor, the KPR, are well represented by its platform and the twenty-seven points of its administrative policies (Minjŏn 1946: 83-85, 87-89). The KPR declared four main objectives: the establishment of an autonomous and independent state; adherence to the principles and ideals of democracy; a rapid elevation of the living standard of the people; and, cooperation with other democratic countries. The administrative policies of the KPR covered more specific social, economic, and political directions for nationstate building. It is worth noting that these policies contained the substantial meaning of civil, political, and social rights as conceptualized by T.H. Marshall ([1949] 1992): freedom of speech, publication, assembly, fraternity, and faith; the enfranchisement of all males and females above the age of eighteen; and, maintenance of the living standards in accordance with the average standard of living. ${ }^{7}$ In particular, maintenance of minimum wages and the abolition of all exorbitant taxes and the usury system clearly show efforts to alleviate the economic burdens of peasants and workers.

Of particular importance is that while promising fundamental freedoms and absolute equality among members of the national community, including the complete emancipation of women, these policies made it clear that those who had collaborated with 
the Japanese would not be considered members of the nation and thus they would not have equal rights. According to the policies, all property, including lands, factories, mines, railways, and communication utilities, owned by the Japanese imperialists or those who collaborated with the colonial power were to be confiscated without any compensation, and to be given to peasants and the state. As these policies indicate, pro-Japanese collaborators became considered "national traitors" (minjok panyŏkcha) and they were denied the right to vote as well. This clearly demonstrates that in the context of liberated Korea, "collaborators" with the Japanese were not considered members of the national community, and the loss of this membership in turn nullified their economic and political rights within the reconstructed political community.

Reflecting this general perception, incidents took place that targeted both remaining Japanese and Korean officials. Right after the liberation, thirty-five Japanese were killed, injured, or attacked, while more than two hundred Koreans, mostly policemen and township officers, encountered similar opposition at the hands of their fellow Koreans (Morita and Osada 1979: 14-15). Since there had been strong antagonism against Japanese colonialism, it is not surprising that people attacked Japanese officials and nationals. What is significant is that people resented other Koreans who had actively served the colonial power more than they did the Japanese. Although the incidents against fellow Koreans occurred only sporadically and did not develop into major political upheaval in the liberation phase, they clearly demonstrate the existence of internal conflicts generated under Japanese colonial rule, which in turn became seeds of social and political contention in the liberation phase.

It should be noted, however, that the meaning of "collaborators" was by no means clearly defined or demarcated. Japanese colonialism lasted for almost four decades with a considerable degree of social penetration of the colonial state, and consequently, all individuals and social groups had to interact with the colonial regime in one way or another throughout the colonial period. In the liberation phase, therefore, the term "collaborators" did not necessarily mean anyone who served the Japanese during the colonial period. The fact that some Korean officials who worked for the colonial state played a leading role in people's committees in a certain county or township (Cumings 1981: 322) reveals that having a particular social and political position in the colonial period itself was not a sufficient criterion for defining collaborators. More important was whether and how they benefited from the Japanese at the expense of fellow Koreans. The ambiguous meaning of "collaborators" 
became clarified when various forms of internal conflicts became intensified through the American occupation period.

\section{The Intensification of Internal Boundaries under the U.S. Occupation}

The political effort to reconstruct a national community during the liberation phase confronted a structural constraint in the form of another foreign rule with the arrival of the U.S. in the south and the U.S.S.R. in the north. If the primary goal of the AMG was to effectively maintain political order, it certainly could have utilized the already existing organizations and activists who were committed to developing mass-oriented politics to the extent that these organizations and associations were supported by the majority of the population. Thus, cooperation with these organizations could have enabled the U.S. to launch democratic political reform more efficiently. Yet, the AMG was reluctant to recognize the political authority and representativeness of the KPR or the people's committees. Instead, it revived the earlier colonial bureaucratic system and filled any vacancies with those Koreans who had served the Japanese before.

The AMG formed a close partnership with a conservative party, the Korean Democratic Party (Han'guk minjudang, hereafter KDP), which consisted mainly of landlords, businessmen, and bureaucrats, who were unwilling to discuss issues of collaboration with the Japanese (Sim 1984: 30, 32). Since the KDP primarily consisted of dominant economic groups, its primary interest lay in maintaining the existing system. The essential objective of the KDP, therefore, was to counteract leftist organizations and their political hegemony. While the party had no specific policies or platforms regarding the construction of an independent nation-state, its manifesto made it clear that the first task of the KDP was to bring down the CPKI and the KPR (Cho 1959: 144). Negating popular organizations and leftist activists was KDP's raison d'être.

When the Military Governor appointed eleven men for an advisory council to assist the AMG, many of whom were conservative and members of the KDP, the KPR claimed that "traitors" were helping the AMG and that the KPR should be recognized as the only legitimate government (Supreme Commander for the Allied Power, September-October 1945: 179). Because the AMG had no clear policy for the occupation, its primary task was to secure law and order, and to maintain the status quo. Reforms that the KPR and the people's committees supported, such as land reform and the redistribution of property, appeared so radical to the AMG that it found them difficult to support. Furthermore, the fact that the KPR 
kept "republic" in its name, implying its governmental character, made its relationship with the AMG contentious. Direct conflict between the AMG and the KPR began to emerge when the AMG announced in a press conference that it was the only legitimate government in the south, thus undermining the political authority of the KPR (Maeil sinbo, October 11, 1945).

The AMG's basic policy from the beginning was to maintain the existing colonial system. Although there was practically no specific guidance and instruction offered to the American army for its occupation rule in Korea, it was indeed instructed that the U.S. forces would utilize Japanese governmental machinery and officials until the development of its own government system (United States Armed Forces in Korea, "History of the United States Armed Forces in Korea," hereafter "HUSAFIK," volume I, chapter 1: 63). On September 23, 1945, the AMG announced that there would be no change of landownership and tax rates. Regarding enemy property, it made clear two days later that the AMG would take control of property owned by the Government-General of Korea, and would allow transactions related to the private property possessed by Japanese nationals. This economic policy gave rise to conflicts between the AMG and local organizations in many regions of Korea, because people's committees already had been playing a role in governmental activities, including taxation and management of land and property since liberation.

Just as the AMG denied the political authority of the KPR, it also launched an initiative to dissolve people's committees at the local level, and to replace them with AMG officers and their appointed Korean counterparts. During this process of reconstructing the local governing bodies, conflicts erupted in many areas. In Namwŏn, a city of the North Chŏlla Province, for instance, the local people's committee took over property, which had been previously owned by the Japanese, during the liberation phase. Upon its arrival in the region, the AMG demanded the property back from the people's committee and nullified its political authority. When the people's committee refused to accept these demands, Korean police intervention promptly followed. Responding to the arrest of five committee leaders by the police, about seven hundred to a thousand people marched into and attacked the police station. When American troops were sent to disperse the crowd, it resulted in three casualties and about fifty injuries (Haebang ilbo, November 25, 1945; United States Armed Forces in Korea, G-2 "Weekly Summary," no. 10, November 11-18, 1945).

As the Namworn case indicates, the AMG relied on the police and military forces in order to enforce its governmental functions. What is critical in this process is that through the intervention of the 
AMG, internal conflicts that had developed during the colonial period became significantly intensified, as those who were perceived to be collaborators made another alliance with the occupation power. In particular, a strong connection between the KDP, a conservative party, and the police force was created through this process. On December 27, 1945, the AMG enacted policies that "the provincial governors were to call on the police to keep order" in local regions ("HUSAFIK," volume III, chapter IV, part one: 11). This policy facilitated the cooperation between the national police force and rightist political organizations to the degree that the members of the KDP already obtained official positions at the provincial and county levels with the help of the U.S. Seventeen out of twenty-one county governors in the South Cholla Province, for instance, were KDP members (Cumings 1981: 155), and both the Director of the National Police Department and the Chief of the Seoul Metropolitan Police came from the KDP.

While rightists gained prominent positions as government officials, leftists wielded a strong influence on various organizations, in part due to their commitment to popular demands for social equality and the removal of Japanese colonial legacies, and in part because of their relatively well-developed organizational and mobilizing capacity, which they had strengthened throughout the colonial period. Although rightist organizations also proliferated during the occupation period, mass organizations in general had a close connection with leftists, whether they were radical communists or moderate nationalists. The Korean Communist Party, for example, played an important role in creating labor and peasant unions in November 1945: the National Council of Korean Labor Unions (Chosŏn nodong chohap chŏn'guk p'yŏngüihoe, henceforth Chŏnp'yŏng) and the National League of Peasant Unions (Chŏn'guk nongmin chohap ch'ong yŏnmaeng, henceforth Chŏnnong).

In particular, the peasant union had local branches in every province, with a total of more than two million members in the U.S. occupation area (Minjŏn 1946: 167). The principles of Chŏnnong resembled those of the CPKI and the KPR. Its economic aims included: the confiscation of all lands from Japanese nationals, collaborators, and national traitors and the redistribution of those lands to poor farmers; prohibition of arbitrary change of tenancy rights by landlords and establishment of union bargaining and contract rights; deduction of rents into one-third of the crop; and, destruction of all usurious loan contracts. Its political goals included: participation of farmers' representatives in government organizations; appointment of executive, judicial, and other important officials through elections; and, supporting and forming close alliances with urban labor movements (Chŏnnong 1946: 101-05). 
As these economic and political objectives indicate, Chŏnnong had a reformist rather than revolutionary characteristic, in spite of the active involvement of the Korean Communist Party. ${ }^{8}$ In response to these leftist initiatives, rightist labor and peasant organizations emerged in 1946 and 1947 respectively, the primary goals and activities of which were to destroy their leftist counterparts and to develop an anti-communist movement.

In short, the U.S. occupation provided both an opportunity for and threat to different social groups. On the one hand, it was an opportunity for those who had a strong interest in maintaining the existing colonial structure, including dominant economic groups and former colonial officials. On the other hand, it represented a critical threat for those who attempted to remove colonial legacies and construct their own independent nation-state. Consequently, various groups had to adopt their own strategies by interacting with the AMG differently, thus exacerbating internal conflicts that culminated in the 1946 uprisings.

\section{The 1946 People's Uprisings}

On September 17, 1946, three thousand railroad workers in Seoul presented a petition to the Department of Transportation with six demands, including a wage increase and food rationing, and requested a response by September 21 . Seven thousand workers in Pusan walked out on September 23 with the same demands, and railroad workers in Korea under the AMG went on a general strike on September 24 (Seoul sinmun, September 25, 1946). More than 250,000 workers affiliated with Chönp'yŏng were mobilized for the general strike that developed into a popular movement. In Seoul, participants included not only about 30,000 factory workers, but also around 6,000 white collar workers, 16,000 students, and 300 professors; in Taegu, one-third of the local population joined the movement (Chosŏn yŏn'gam 1948: 257-58).

The general strike in September was followed by the outbreak of October uprisings. On October 1, Taegu became the center of protest, where women and children went to the city hall to demand rice, and sympathetic union workers gathered at the railroad station. When the police fired into the crowd to disperse them and killed a protestor, it fanned the flames of anger. The next day, thousands of high school and college students carrying the dead body entered the police station, released prisoners, and took weapons. Protestors took over the police station and began to attack policemen and government officers. U.S. troops arrived to control the situation and accepted the students' demands: approval of the legitimacy of the strikes, immediate release of the arrested, 
and suspension of repressive tactics. The crowds dispersed and martial law was imposed. In the North and South Kyŏngsang provinces, thirty-seven towns saw the outbreak of uprisings from the first to the tenth of October. The number of participants ranged from forty to tens of thousands ("HUSAFIK," volume III, chapter 4, part two: 7-8). After the movement in the Kyongsang provinces, uprisings took place sporadically in other regions covering all provinces in the south until mid-December (see Figure 1).

The uprisings were crushed especially by the police force, which caused extensive damage and casualties. It was reported that by the end of October, forty-four police officers and forty-three civilian casualties occurred in North Kyŏngsang Province alone (Chosŏn ilbo, October 31, 1946). While there are no official government statistics about the extent of the uprising, reliable estimates from scholars suggest that about two million people

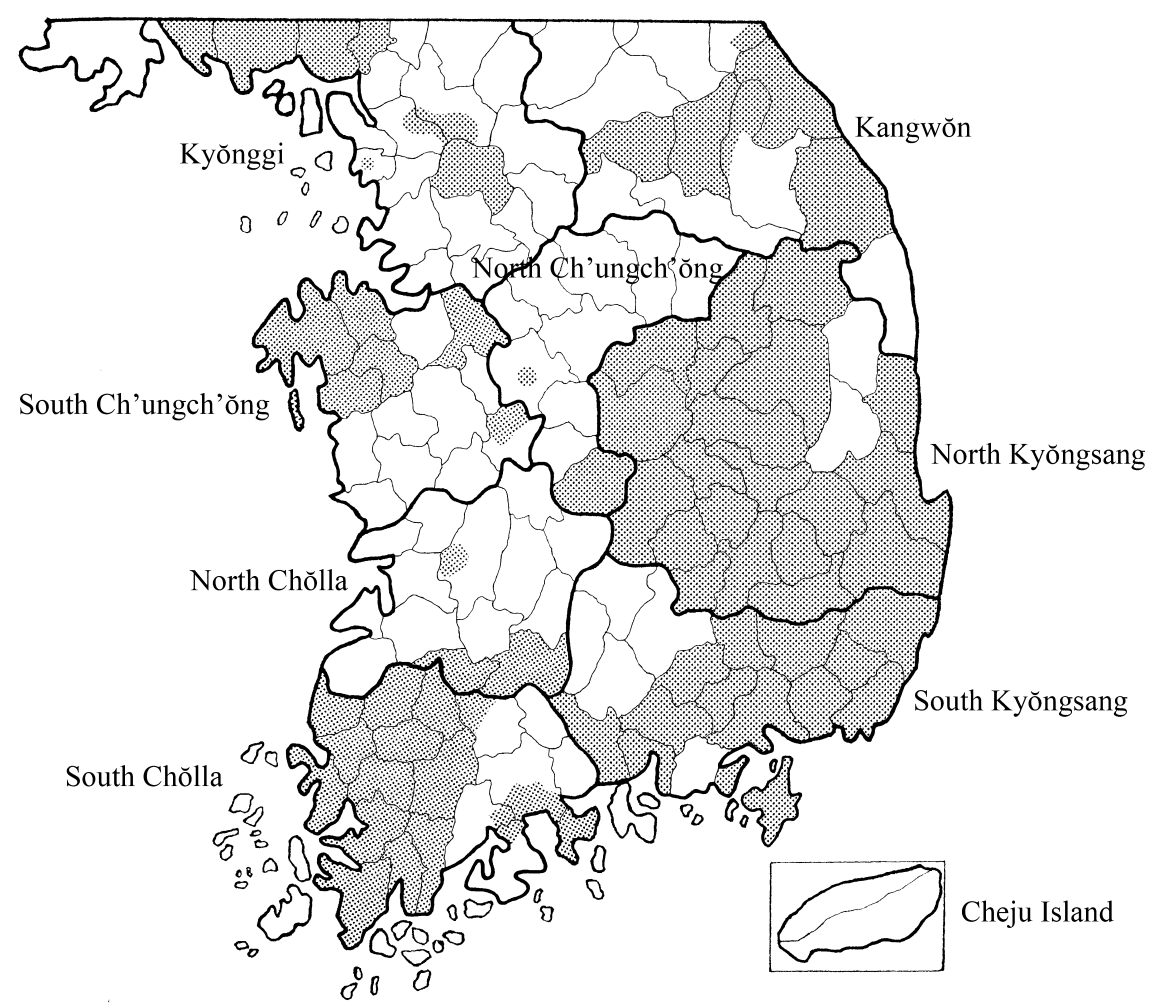

Figure 1: Incidents of Uprisings, September-December 1946 Redrawn from maps of uprisings from Chŏng (1988: 190) and Cumings (1981: 353) with their permission. Shaded areas indicate at least one incident and black lines represent provincial boundaries 
participated in the general strike and subsequent uprisings, and that movement casualties for the entire period include more than two hundred policemen and about one thousand participants (Cumings 1981: 379).

Although people attacked police stations and government employees throughout the movement, American officials never became targets. When railroad workers organized a general strike in September and submitted a petition with their demands to the Military Governor, for instance, it could have developed into an anti-AMG political movement to the degree that the employer was the Department of Transportation. Instead, it caused a massive physical confrontation between strikers cooperating with union activists and rightist organizations, especially youth associations, backed by the police. It was reported that about one thousand union members were arrested (Chosŏn ilbo, October 2, 1946).

One might argue that attacks on police officers and bureaucrats occurred as a result of the anti-government bent of the movement. To be sure, the positive attitudes toward the U.S. that the general public held turned critical against the AMG, and the 1946 uprisings took place as a consequence of the economic and political policies implemented by the AMG. ${ }^{9}$ That the movement was fueled by anti-U.S. resentment only, however, does not seem to sufficiently explain several stubborn historical facts: first, not a single American official was attacked throughout the uprisings; second, people who were not directly involved with the AMG, such as big landlords, also became targets of the movement; third, the degree of antagonism and violence that movement participants employed against fellow Koreans was too intense and ruthless to be considered an indirect expression of anti-U.S. sentiment.

Military government documents describe the brutal methods people used to attack fellow Koreans as follows. In Taegu, for example, "faces and bodies of policemen were hacked by axes and knives. The hands of policemen were tied behind their backs and sharp-pointed slate rocks were then thrown at them until they fell to the ground from loss of blood. This was followed with dropping large boulders on their heads crushing them beyond recognition. In Waegwan, the police chief's eyes and tongue were cut out with rice knives before he was beaten to death. And, in Sangju, five policemen were severely beaten and buried alive" ("HUSAFIK," volume III, chapter 4, part two: 23). Even hospitals in Taegu refused to treat wounded policemen (Haebang hu sanyŏn kan ŭi nambanbu inmin tulŭi kuguk t'ujaeng 1949: 33). ${ }^{10}$ If the AMG itself was the ultimate source of motivation for the movement, it seems unlikely that participants would have utilized such brutal methods against fellow Koreans. In short, 
anti-government tendencies alone cannot account for the movement's intense violence and choice of targets.

Rather, policies implemented by the AMG fueled the sources of people's grievances, which culminated in the uprisings. Economically, the AMG introduced a free market policy and revived the colonial practice of grain collection in spite of public outrage directed at these practices. In doing so, it exacerbated economic conditions enough to threaten subsistence levels for peasants and workers. Politically, the occupation regime supported conservative political groups and reincorporated those who actively served the Japanese colonial power, while suppressing progressive activists and voluntary social organizations. To achieve a more comprehensive understanding of the uprisings, therefore, it is necessary to see how internal conflicts were exacerbated through these specific economic and political policies by AMG.

Korean police officers and bureaucrats became the main targets throughout the uprisings not simply because they worked for the AMG, but more importantly due to their past conduct and relationships with other social groups since the colonial era. Pak Tu-p'o, who was a teacher in Ch'ilsŏng elementary school during the colonial period and a resident in Taegu in 1946 describes his observation as follows (interview with author, May 7, 2008):

Later, I saw him [a police officer] sitting on the street. He was bleeding. It looked like he had been beaten. Tens of people were surrounding him, [they shouted], 'this guy has burdened us. He should be beaten to death, he shouldn't stay alive.' Whether men or women, they were cursing him. He was sitting on the street with his eyes closed. He was active in the conscription and draft for the war during the colonial period. [. . .] After liberation, collaborators [with the Japanese] like him ran away and looked for a mouse-hole to hide themselves. But, they occupied high-ranking government positions and police departments again after the U.S. came. Grudges kept growing and growing.

Having no clear political orientation and policies, the AMG brought the colonial state structure back and many government officials who worked for the Japanese regained their positions under the U.S. More than eighty percent of the Korean police force under the AMG, for example, had served the colonial state (An 1988: 215; Henderson 1968: 85). Throughout the occupation period, the police force was intensively utilized to oppress such organizations as people's committees, labor and peasant unions, and leftist political groups. In fact, it was Cho Pyŏng-ok, the Director of the National Police Department and a member of KDP, who suggested that the AMG should ban people's committees and the KPR, while tolerating the violence of rightist organizations (Cho 1959: 154-56).

Reporting police oppression against workers' and farmers' associations and the prevalent use of harsh Japanese methods for 
prisoner treatment, the Department of Public Information of the AMG in July 1946 noted that "the apparent recent increase in police aggression and brutality has been carefully planned. The pass word is 'August 15 revenge,' the idea being to mete out vengeance to those who removed the Japanese police from office last August [in 1945]" (United States Armed Forces in Korea, "Civil Disturbance," no. 2, [July 30, 1946] 1994: 187, emphasis added). It is not clear whether or how systematically police aggression was planned. What is clear is that political oppression toward popular demands and organizations took place at local as well as institutional levels. Although the U.S. played an important role in this process by bringing back colonial institutional settings and personnel in the political field, the critical point is that the oppression was intensified by the active and voluntary intervention of police and rightist political organizations.

Why did Korean police and bureaucrats initiate political oppression against popular associations and activities under the AMG? To comprehend the voluntary characteristic of the police oppression and the continuity from Japanese colonial into American occupation periods, it is crucial to understand the role of the liberation phase. As discussed earlier, in the liberation phase, the most important task was to eliminate colonial legacies and reconstruct an independent national community. People's committees in many areas took over governmental administrative roles, and those who worked for the Japanese and lost their people's faith were largely ousted. Yi Il-jae, a labor movement activist affiliated with Chonp'yŏng and a participant in the 1946 uprisings in Taegu recalls (interview with author, May 22, 2008):

[During Japanese colonialism], there was a Korean chief at the township office in our village. When there were any kinds of disputes, he called for the police to break them up. [. . .] He exempted those people he knew well from the forced draft [for the war effort during the late colonial period] and instead forced others to go in order to increase his work performance. Right after liberation, people hit him in the head with shovels and threw him into a rice paddy. We thought that he was dead. But, he then showed up in the town again and was reappointed by the AMG. Later, people attacked him during the uprisings.

This statement illustrates how the internal conflict, which was produced during the colonial period in the form of the relationship between government officials and ordinary people, was intensified through liberation and the later occupation period. In the liberation phase, popular antagonism against the Japanese was largely directed toward Korean officials. Upon U.S. arrival in the south, they returned to their positions seeking their own survival and reprisals, which in turn reinforced popular grievances and percep- 
tions of injustice. Indeed, a leaflet found in Paekch'ŏn reads "it is our aim to remove the evil police who repress our true patriots, vicious bureaucrats who exploit excessive food, and pro-Japanese national traitors who are behind them" (Chŏng 1988: 217, emphasis added). In this regard, one of the important roles of the liberation phase can be found in the bridging of internal boundaries among Korean people from the colonial through U.S. occupation periods.

The economic situation was as important as the issue of political oppression in sparking the uprisings. Of particular importance for understanding economic issues are the AMG's "free market" policies and subsequent implementation of the grain collection program. As soon as the AMG launched its occupation activities, it adopted free market policies and issued "Free Market Rice" (General Notice, no. 1, October 5, 1945) and "Free Market" notices (General Notice, no. 2, October 20, 1945). The primary goal of these two notices was to remove all control and restrictions on the rice market and on the sales of all commodities, thus stimulating trade and economic production. The consequences of these free market policies, however, were the emergence of tremendous inflation and the disappearance of rice in the open market. Within one year after the U.S. came, the price of polished rice increased almost three hundred times and the average cost of food was one hundred times higher than in the pre-war period ("HUSAFIK," volume IV, chapter 6: 5, 27; Lauterback 1947: 237).

Facing a widespread shortage of rice, the AMG announced a "National Rice Collection" (Ordinance, no. 45, January 25, 1946) in order to secure food rations. Reviving the notorious grain collection program, which had been practiced for the war effort in the early 1940 s during the Japanese colonial period, the ordinance mandated that each farmer deliver all excess rice except for 2.25 bushels per person in each household. As the total amount of the first rice collection reached a mere 13.6 percent of the originally intended amount, the AMG issued the "National Food Regulation, no. 2" on August 12, 1946, and changed the method for rice collection. Unlike the preceding method, this regulation mandated that each farmer deliver a certain amount of an assigned quota to the AMG at a fixed price. Local boards became responsible for allocation and collection, which consisted of police officials, village elders, business men, and large landowners.

The free market policies and grain collection program brought about contrasting results for different economic groups. While they led to extreme poverty and hunger threatening the subsistence level for peasants, landlords were able to enhance their economic power. The problem with the forced grain collection was that it was executed under exacerbated economic conditions, and the price of 
collection was less than twenty percent of the production costs (In 1949: 79). Describing the living conditions in the summer of 1946 , an AMG document noted that "there are large numbers of people every day who come to the village office to ask for food. About 1,500 people are suffering from a growth on their skin, which is due to the shortage of food and many of them have died" (G-2 "Weekly Summary," no. 43, June 30-July 7, 1946). In contrast, landlords could escape heavy allocation through their close relationships with government employees. The fact that quota allocation was decided in local administrative offices seems to be chiefly responsible for the assignment of heavy allocation for farmers. Since the colonial period, landlords played a central role in local offices and thus they could shift proportionate allocation to farmers. When farmers submitted their rice to the government office, for example, Korean clerks gave them only half credit for the rice and assigned the remaining credit to the landlords (Gayn 1948: 414). Landlords also actively used the situation to their benefit by lending money to farmers at higher interest rates than during the colonial period. ${ }^{11}$

The AMG's economic policies significantly aggravated the already insecure economic position of peasants who had suffered from tenancy rights and high rents. To be sure, the AMG enacted a rule that maximum tenancy rent should not exceed one-third of the crop in the early occupation period. Due to the population influx after liberation, which resulted in considerable surplus labor, however, it was also possible for landlords to evade the ordinance and force tenants to pay high rents as a condition of continuing their tenancy rights. Indeed, from 1946 through August of 1947, there were 1,552 tenant disputes in the North Kyŏngsang Province, about eighty percent of which were related to the demand of continued tenancy (Kyŏngbuk yŏn'gam 1948: 206-07). ${ }^{12}$ The economic problems, which had existed since the colonial period, including excessive rents, insecure tenancy, and usury, reappeared and were considerably aggravated under the AMG.

It should be noted that landlords also played an important role in the policy-making process. As the food situation was aggravated after the enactment of the free market policies for rice, the AMG called for an informal gathering and about twenty large landlords were invited. In the meeting, a lieutenant colonel said, "though rice began to be sold in a free market as you wanted from the outset, you increased the price of rice. Even more, you don't put rice out on the market as the price control began to be in effect. The food problem became extremely exacerbated and we even detected places for rice concealment. Although we are willing to give you a last chance to put rice out on the market and regulate the price accordingly, if you 
keep pursuing your selfish interest only and continue to exert a harmful influence on Korean independence, we cannot but take coercive resolution" (Chosŏn ilbo, January 10, 1946, emphasis added). This statement reveals that landlords were directly involved with the AMG's free market policy-making process from the beginning and sought to maximize their interest by manipulating the economic situation.

Reflecting this economic condition, there occurred some incidents in which people resisted landlords throughout the uprisings. When the protest took place in Yorngch'onn in the North Kyŏngsang Province, for instance, twenty landlords and twentyfour police officers or bureaucrats were killed, and about one hundred people severely wounded. Among the landlords, Yi In-sŏk, the father of Yi Hwal, a leading member of the KDP, was brutally attacked (Siwŏl inmin hangjaeng 1947: 46). Compared to bureaucrats and police officers, landlords had not been the main target of attack during the uprisings. It is worth emphasizing, however, that the political and economic elite tended to overlap. During the colonial period, some Koreans who enjoyed dominant economic status worked for local governing bodies. In fact, representatives in the upper level administration $(p u)$ included both landlords and capitalists, and more than ninety percent of people in the local offices (myŏn) engaged in agriculture in 1931 (Chōsen sōtokufu naimukyoku 1932: 286-90). Since the colonial government endowed electoral eligibility for local councils to people who paid more than five yen in local taxes for economic property, it is plausible to regard most local representatives as landlords. By working closely with the colonial power, therefore, dominant economic groups were able to maintain and expand their economic interest and political power. The economic and political elites by no means existed as a unitary group, and yet they were not completely disconnected either.

The cooperative relationship among landlords, bureaucrats, and the police was reinforced during the occupation period, especially in the process of grain collection. In fact, the Department of Public Information of the AMG reported two months before the outbreak of uprisings that village officials who were closely connected to large landlords set grain quotas long before the harvest and worked with police officers. When farmers refused to submit or complained of unfair quotas to the local offices, they were jailed, whether they had grain or not, and received bad treatment from police. Local Farmers' Associations did not receive any representative rights and were subject to police raid. For many, "the police were no better than the former Japanese police" ("Civil Disturbance," no. 2, [July 30, 1946] 1994: 186). 
At that time, our living conditions were really bad because of inflation. After the Japanese defeat, it was said that it became our world, but an official who served the Japanese was still overbearing at the village office. That Korean official was like a devil of a man in terms of rice collection during the Japanese colonial period. If people did not meet the heavy allocation, the official made them kneel down when it was raining and robbed their grain. People didn't like that such a person was still holding the same position even after liberation. The official was a wealthy farmer at another village which was ten $r i$ [about 2.5 miles] away from our village. Of course, he made a good fortune because he worked with the Japanese.

The above testimony (Yi 1965: 230-31) shows how the forced rice collection during the colonial period reinforced internal conflicts among the Koreans. Even though the rice collection was implemented by the colonial state for its war effort, it provided some Koreans with a chance to expand economic and political power at the expense of their fellow countrymen. When the AMG revived the grain collection program, and particularly after utilizing the methods that were more extractive and brutal, the internal conflicts among Koreans reappeared in intensified form. The animosity against former colonial officials is evident in the statement of Kang Ch'ang-dŏk, a low-ranking officer of the Department of Agricultural Economy at the provincial government office who participated in the protest in front of a police station in Taegu on October 1. His statement illustrates a deep rooted antagonism against former colonial officials and provides a clue about the source of their anger. Reflecting on the events that transpired the following day, he recalls (interview with author, May 7, 2008):

On my way from work, I saw a lot of stuff piled in the street and people surrounding it. It was a high-ranking government employee's house, who'd lost favor with the people during the Japanese colonial period. They searched his house and found a lot of rice, sugar, and cotton fabric. This kind of stuff was really precious back then. People didn't take the stuff for themselves but put it in the street and shouted 'see this, now people are poorly clothed and suffering from hunger, and this son of bitch is living well against the people.' They cursed him and shouted he should be beaten to death.

The incident took place after the police station was taken over. Although it was more or less a spontaneous invasion against colonial bureaucrats rather than an organized collective action with clearly defined goals, it illustrates some of the sources of shared hostility toward government officers who collaborated with the Japanese colonial government and then the American military occupation. In short, popular resentment stemmed from the fact that people who prospered and protected themselves under the aegis of Japanese power not only maintained their positions, but 
even increased their economic and political power under U.S. occupation while the standard of living for most people was on the edge of subsistence levels.

It seems that extortion by bureaucrats and police officers was widespread. Noting that after the outbreak of uprisings in Taegu, an average of three sǒk (about 143 gallons) of rice was found in murdered policemen's houses, an American observer stated that "it was impossible that such a large amount could have been acquired legally. Obviously, there had been a large-scale police shakedown operating in the area" (Robinson 1950: 151). What is noteworthy is not only that officials had a large amount of food when most people were suffering from starvation, but also that movement participants did not take the food with them. As indicated in the above statement, even in an unorganized and impulsive collective action, people did not appropriate the officials' property. Rather, they directed their collective grievances and antagonisms towards those who they felt did not deserve their powerful positions and who prospered at the expense of fellow Koreans under the protection of the U.S. Even though there is no doubt that a dearth of food provoked collective grievances, hunger alone does not seem to explain the deeper meaning and motivation of the uprisings.

To understand why people so vehemently protested against fellow Koreans throughout the uprisings, then, it is critical to consider the meaning of liberation. The following statement (Yi 1965: 230-31) highlights what liberation meant for ordinary people.

After liberation, he [the colonial official] was maintaining the same living condition as he had during the Japanese colonial period. People considered going to the village office [during the uprisings] as a chance to revenge vicious grain collection. [. . .] They destroyed the village office and put documents in the fire. Staff at the office couldn't stop them. Police officers and other officials ran away. People got excited and went to the village where the target of their resentment, the vicious proJapanese official lived. His house and assets were wrecked and burnt down. People came back to the town after putting even his family treasure in the fire. That night was like a village feast for them. Having home-brewed wine and turning red-faced, they enjoyed their complete retaliation and triumph as if it had become a truly free world.

For most people, liberation from Japanese colonial rule meant the removal of colonial legacies and the reconstruction of their own political community. In this regard, the uprisings can be considered as a people's response to their negated right to livelihood, right to participate, and, most importantly, right to belong to their own community that they had longed for since the colonial period. The problem lay partly in the fact that the nationalist aspiration of achieving an independent nation-state became identified by the AMG with a communistic orientation. Also important is the fact 
that these demands and rights could be interpreted as the negation of membership in the national community of those who had worked for and prospered through Japanese colonialism.

The experience of the liberation phase, albeit brief, underscored that "collaborators" with the Japanese had no economic, political, and social rights in a newly-reorganized political community. Although the meaning of collaborators remained relatively ambiguous and subject to interpretation, what is crucial is that those who served or benefited from Japanese colonial domination, and then the AMG at the expense of other Koreans, suppressed the people's demands not simply because of the commands they received from the Americans, but for their own survival. If internal conflicts among Koreans took the form of "life-and-death" struggles during the occupation period, as the 1946 uprisings indicated, this was due to the internal exclusion that had been produced and redeployed since the colonial period.

In sum, the significance of the uprisings lies in the fact that they were pivotal events through which internal boundaries that had been created during the colonial period became intensified and reclassified under the American occupation. Since the colonial period, internal boundaries had taken various forms, including economic conflict between landlords and peasants, ideological conflict between liberal and socialist nationalists, and political conflict between police officers/bureaucrats and peasants/workers. Despite the existence of a general affinity across these boundaries, they tended to coexist with each other and did not develop a clear demarcation during the colonial and liberation periods. When internal conflicts were intensified under the AMG, however, the demarcation of boundaries began to emerge between those who sought to reproduce the existing system, including dominant economic groups, former colonial officials, and the AMG on the one hand, and those who struggled against the attempts to revive colonial structures and practices, particularly peasants, workers, and leftists, on the other. The 1946 uprisings were generated when these different forms of conflict coalesced in a particular historical conjuncture.

\section{The Aftermath of Uprisings}

The repercussions of the uprisings on the subsequent political landscape were far reaching. First, people lost their organizations and the despotic colonial state structure was in turn revived. Throughout the uprisings, voluntary social associations and political organizations, such as people's committees and farmers' and workers' unions, which had already been under political suppression, were largely destroyed. In this process, the coercive state 
apparatus that had been nurtured under the Japanese colonial rule, particularly the police force, reappeared in new form with even more strength. In fact, an additional budget was assigned to supplement and reinforce the police force in November of 1946 during the uprisings, and the annual expenditure for the National Police Department increased about sixty percent in 1947 (Chosŏn kyŏngje yŏnbo 1948: 267). As a result, while Korean police officials numbered about 10,000 for the entire area of Korea in the late colonial period, they expanded to approximately 25,000 in the south only in the aftermath of the uprisings in 1946, then to 45,000 right before the establishment of a separate government in South Korea in 1948 (An 1988: 211). The enhanced police force was brutally and effectively utilized for controlling subsequent popular struggles against the establishment of a separate nation-state in the south.

Another significant impact of the uprisings on the subsequent political process is related to the fact that rightists largely secured their positions in the institutionalized political field. From the beginning, rightists tended to dominate official positions and worked with the AMG more closely than leftists. Leftists, however, had maintained relatively developed organizations and popular memberships that they could more easily mobilize. When the first general election under the U.S. occupation was held for the Interim Legislative Assembly in late October, while the uprisings were taking place, most of the prominent leftists were either already in prison or driven underground to escape political oppression. In fact, the prisoners in the south numbered around 22,000, which was almost twice the highest number of convicts at any point during the Japanese colonial period (Robinson 1950: 146). Consequently, among the forty-five members who were elected, only two members from the people's committee were elected from the island of Cheju Province, and a majority of the members were from rightist parties. Although leftists continued to be more or less marginalized since the arrival of the U.S., rightists secured and strengthened their positions by effectively expelling leftists from the institutionalized political field through the uprisings.

The significance of the election lay not merely in the underrepresentation of leftists but also in the fact that both the procedure and practice was far from democratic. The principal of universal suffrage was announced and yet voices of individual voters could hardly be heard. Indeed, "in hundreds of cases, the village and county heads dispatched servants to the prospective voters, asking for the loan of their name seals, which were then stamped on ballots filled in by the officials" (Gayn 1948: 426). Even though the Interim Legislative Assembly had a limited effect on the 
subsequent political landscape, an important consequence of the first election was the alienation of popular voices and the elimination of divergent ideological ideas from institutionalized political processes, thus developing an exclusionary mechanism that came to characterize political structure in the south.

\section{Conclusion}

Understanding Japanese colonial rule in Korea is essential for explaining the subsequent liberation and U.S. occupation periods. While colonial rule was a threat to the Korean people as a whole, various groups responded to and interacted with the colonial power by using different strategies from which contentious relationships among indigenous people were generated and rearticulated. In this sense, a critical consequence of colonial rule can be found not only in producing a structure of economic exploitation and political oppression, but perhaps more importantly in generating and amplifying internal boundaries among the indigenous people. Indeed, in the aftermath of Japanese colonialism, there emerged significant conflicts as a consequence of the incompatibilities between national and political communities. The fact that collaborators with the Japanese colonial power became identified as "national traitors" and became the target of popular protests shows how the meaning of social membership in a national community can be altered through the historical experience of colonial domination. In this regard, the social consequences of the colonial experience are among the most profound colonial legacies.

The centralized state structure that the Japanese colonial power introduced in Korea was reproduced in postcolonial South Korea. The colonial state structure, however, did not immediately determine the form and characteristics of the postcolonial state. The continuity from colonial to postcolonial was realized through the historical process of liberation and the American occupation periods. In fact, the strongly centralized state form could have been effectively used as an institutional resource for developing a postcolonial nation-state in Korea. The character of the postcolonial state, rather, hinged on who utilized the colonial state structure and for what ends. When right leaning conservative, whose legitimacy was significantly tainted, utilized colonial structures against popular demands for economic and political reforms under the aegis of the AMG as another super-imposed foreign power, the coercive characteristics of the colonial structure were in turn revived in a more transparent form. In this sense, internal boundaries were resurrected, rendered more visible, and thus constituted powerful sources of political conflict during the liberation and 
occupation periods, the important consequence of which lies in the pattern of internal exclusion that typified South Korea's post-war political trajectory.

Even though the ways in which Japanese colonial rule influenced postcolonial state formation in South Korea should be understood in its particular historical context, it provides a more general lesson for understanding other postcolonial societies. Like South Korea, most colonial societies underwent different forms of social and political conflicts in postcolonial periods. In South East Asia, for instance, India and Pakistan experienced a devastating civil war because of their dispute over the national border and religious conflicts. In many parts of Africa, tribal and ethnic divisions gave rise to serious political eruptions. The implication of this analysis of Korea lies in the claim that it is crucial to examine how the historical experience of colonial domination produces and reshapes sources of internal conflict, whether religious, ethnic, or classbased, among indigenous people, and how such conflict in turn plays a pivotal role in shaping a particular state form and political trajectory in postcolonial societies.

\section{Acknowledgments}

I owe special gratitude to Howard Kimeldorf for encouraging the project at every stage with his invaluable advice and thoughtful comments. For their generous feedback on written drafts, I am grateful to Avi Aastor, Henry Em, Marco Garrido, Greta Krippner, Sandra Levitsky, Rachel Schroeder, Margaret Somers, and the JHS Editor and referee. Finally, I thank participants in the 2010 annual meeting of the American Sociological Association and the 20092010 Korea Foundation Fellows Presentation at the Nam Center for Korean Studies at the University of Michigan, where earlier drafts were presented. Direct all correspondence to the author, Department of Sociology, Yonsei University, Seoul, Korea.

\section{Notes}

1 The movement has been referred to in different ways, including autumn harvest uprisings (Cumings 1981), October people's uprisings (Chŏng 1988), Taegu October uprisings (Sim 1991), or peasant uprisings of 1946 (Shin 1994). Throughout this article, the movement is referred to as the uprisings.

2 Just as the colonial state interacts with different indigenous groups in various ways in a certain colonial society, an imperial power can also have divergent forms of colonial rule in different contexts (see Steinmetz 2007). In this regard, the particular characteristics of a colonial state need to be understood at specific historical moments. 
${ }^{3}$ Smith rejects both modernists who argue that the nation is a purely modern phenomenon, and perennialists who contend that nations and nationalism have always existed throughout history. To overcome the two perspectives, he takes the middle ground and suggests some continuity between traditional and modern eras through the concept of ethnie or ethnic community. Thus the existence of a sense of solidarity in the Chosŏn dynasty does not necessarily mean that Koreans had developed a modern form of nationalism in the pre-colonial period.

${ }^{4}$ It should be noted that the term "homogeneity" here primarily refers to ethnic and cultural dimensions. Therefore, the homogeneous character of Korea in the pre-colonial period does not suggest that traditional Korea had existed as an essentially harmonious collective entity without any social conflict. In fact, the Chosŏn dynasty had maintained a hierarchical social status system in which each individual belonged to a different social category. In this sense, I do not share the nationalistic assumption that traditional society had existed as an undivided and essential entity (see Prakash 1995: 388-91).

${ }^{5}$ Cumings (1981: 360) notes that a missionary was killed in Kigye, a village of Yŏngil County in the North Kyŏngsang Province, which was the only incident against non-Koreans throughout the uprisings. Chŏng (1988: 125), however, explains that rightist leaders and a Korean missionary, An Kang-bok, were assaulted and found dead at the same place. It is not clear whether the two missionaries are the same person or not. Even if they were two different missionaries, and therefore there was a non-Korean casualty, however, the point seems to remain valid that there were no major incidents related to Americans during the uprisings and almost all attacks targeted fellow Koreans.

${ }^{6}$ This national organization was initiated when the colonial power requested two prominent nationalists, Yŏ Un-hyŏng and An Chae-hong, to protect the Japanese and maintain public order until the Allied Forces arrived, and was based on acceptance of the nationalists' five conditions: the immediate release of imprisoned political offenders; the guarantee of food provisions for three months from August to October; no intervention in any political activity for public security and state building; no intervention in organizing students and youths; and, no intervention in mobilizing farmers and workers for the construction of the nation-state (Maeil sinbo, August 17, 1946).

7 Marshall classifies citizenship into three elements: civil, political, and social rights. For Marshall, civil rights represent individual freedoms, such as property rights, political rights indicate the right to participate in political activities, and social rights exhibit the right to social justice. In particular, Marshall (1992: 8) defines social rights as "the whole range from the right to a modicum of economic welfare and security to the right to share to the full in the social heritage and to live the life of a civilized being according to the standards prevailing in the society." In this sense, "maintenance of the living standards in accordance with the average standard of living," as indicated in the KPR's policies, can be interpreted as pertaining not just to economic welfare, but also to social rights of community membership.

8 These objectives seem to reflect the view the general public held that the construction of an independent nation-state should be accomplished before any fundamental economic reforms. Indeed, when the AMG announced a plan for the sale of Japanese-owned land solely to tenants 
with payment in produce in March 1946, a majority of tenant farmers indicated through public opinion polls that the establishment of a "Korean" government should be prioritized over any land reform, and only fourteen percent of them favored an immediate land distribution by the AMG. Also, regarding the Korean-owned land, eighty percent of respondents agreed to its sale to tenant peasants, rather than free distribution (Robinson 1950: 85).

9 A survey of public opinion, conducted by the Department of Public Information of the AMG in the middle of 1946 sampling about 8,500 people in all provinces of Korea under the rule of $A M G$, indicated that for the question concerning their attitude towards the AMG, 28\% responded as satisfied, 38\% as dissatisfied, and 34\% did not know how they felt (G-2 "Weekly Summary," no. 50, August 18-25, 1946).

10 The Taegu Doctor's Association demanded that the AMG "stop the police from shooting the citizens. We will refuse medical treatment to the police who shoot the citizens." As doctors refused to treat the police, the hospital was taken by the U.S. Army medical personnel (G-2 "Weekly Summary," no. 60, October 27-November 3, 1946).

11 While rural credit associations under Japanese colonial rule led farmers to borrow money at a rate of twenty-four percent a year, landlords requested rates as high as sixty percent (Gayn 1948: 414).

${ }^{12}$ In 1947, the number of tenant disputes increased to 1,934 by August, 1,552 of which were caused by tenancy issues. Although the AMG implemented a "one-third" policy to alleviate tenants' economic burden from the demand for high rents by landlords, it was blamed for reinforcing their landownership, thus enabling them to maintain their economic power, which declined significantly during the liberation phase (Chŏnnong 1946: 159).

\section{References}

An, Chin. 1988. "Migunjŏng kyŏngch'al ŭi hyŏngsŏng kwajŏng kwa kŭ sŏnggyŏk e kwanhan koch'al" [A Study of the Formation Processes and Characteristics of the Police Force during the U.S. Occupation Period]. Pp. 198-228 in Haebang chikhu ǔi minjok munje wa sahoe undong edited by Han'guk sahoesa yŏn'guhoe. Seoul: Munhak kwa chisŏngsa.

Chatterjee, Partha. 1993. The Nation and its Fragments: Colonial and Postcolonial Histories. Princeton, NJ: Princeton University Press.

Cho, Pyŏng-ok. 1959. Na ǔi hoegorok [My Recollections]. Seoul: Min'gyosa.

Ch'oe, Chang-jip. 1987. "Han'guk ŭi ch'ogi kukka hyŏngsŏng ŭi sŏnggyŏk kwa kujo, 1945-1948" [Structure and Characteristics of State Formation in Korea, 1945-1948]. Pp. 75-138 in Sanŏp sahoe yŏn'gu edited by Han'guk sanŏp sahoe yŏn'guhoe. Vol. 2. Seoul: Hanul.

Chŏng, Hae-gu. 1988. Siwŏl inmin hangjaeng yŏn'gu [A Study of the October People's Uprisings]. Seoul: Yŏrŭmsa.

Chŏn'guk nongmin chohap ch'ong yŏnmaeng sŏgibu (Chŏnnong). 1946. Chŏn'guk nongmin chohap ch'ong yŏnmaeng kyŏlsŏng taehoe ǔisarok [Minutes from the Inaugural Meeting for the National League of Peasant Unions]. Seoul: Chosŏn chŏngp'ansa.

Chōsen sōtokufu naimukyoku. 1932. Kaisei Chōsen chihō seido jisshi gaiyō [Summary of Revised Local Government System in Korea]. Keijō [Seoul].

Chosŏn ilbo [Chosŏn Daily]. 1946. Seoul: Chosŏn ilbosa.

Chosŏn kyŏngje yŏnbo [Annual Economic Review of Korea]. 1948. Seoul: Chosŏn ŭnhaeng chosabu. 
Chosŏn yŏn'gam [Korea Yearbook]. 1948. Seoul: Chosŏn t'ongsinsa.

Cooper, Frederick. 2005. Colonialism in Question: Theory, Knowledge, History. Berkeley: University of California Press.

Cumings, Bruce. 1981. The Origins of the Korean War: Liberation and the Emergence of Separate Regimes 1945-1947. Vol. 1. Princeton, NJ: Princeton University Press.

-. 1984. "The Legacy of Japanese Colonialism in Korea." Pp. 478-96 in The Japanese Colonial Empire, 1895-1945 edited by Ramon H. Myers and Mark R. Peattie. Princeton, NJ: Princeton University Press.

Davidson, Basil. 1992. The Black Man's Burden: Africa and the Curse of the Nation-State. London: James Currey.

Duncan, John. 1998. "Proto-nationalism in Premodern Korea." Pp. 198221 in Perspectives on Korea edited by Sang-oak Lee and Duk-soo Park. Sydney: Wild Peony; Honolulu, Hawaii: International distribution by University of Hawaii Press.

Em, Henry. 1999. "Minjok as a Modern and Democratic Construct: Sin Ch'ae-ho's Historiography." Pp. 336-62 in Colonial Modernity in Korea edited by Gi-wook Shin and Michael Robinson. Cambridge, MA: Harvard University Press.

Gayn, Mark. 1948. Japan Diary. New York: William Sloane Associates.

Goswami, Manu. 2004. Producing India: from Colonial Economy to National Space. Chicago: University of Chicago Press.

Haebang hu sanyŏn kan ǔi nambanbu inmin tul ǔi kuguk t'ujaeng [People's Movements for Saving the Nation in the Southern Half of Korea for Four Years after Liberation]. 1949. Munhwa sŏnjŏnsŏng.

Haebang ilbo [Liberation Daily]. 1945. Seoul: Haebang ilbosa.

Henderson, Gregory. 1968. Korea: The Politics of the Vortex. Cambridge, MA: Harvard University Press.

Hong, In-suk. 1985. "Kŏn'guk chunbi wiwŏnhoe ŭi chojik kwa hwaltong” [The Organization and Activities of the Committee for the Preparation of Korean Independence]. Pp. 57-103 in Haebang chŏnhusa ŭi insik edited by Man-gil Kang et al. Vol. 2. Seoul: Han'gilsa.

In, Chŏng-sik. 1949. Chosŏn nongŏp kyŏngjeron [A Study of the Agricultural Economy in Korea]. Seoul: Pangmun ch'ulp'ansa.

Isaacman, Allen and Barbara Isaacman. 1977. "Resistance and Collaboration in Southern and Central Africa, c. 1850-1920." International Journal of African Historical Studies 10: 31-62.

Kang, Ch'ang-dŏk. 2008. Interview conducted by author in Taegu on May 7.

Kim, Nam-sik. 1984. Namrodang yŏn'gu [A Study of the Labor Party in South Korea]. Seoul: Tolbegae.

Kim, Tong-no. 1998. "Migunjŏnggi ŭi nongmin chojik kwa nongmin undong" [Peasant Organizations and Movements during the U.S. Occupation Period]. Sahoe wa yŏksa 54: 121-63.

Kohli, Atul. 1990. Democracy and Discontent: India's Growing Crisis of Governability. Cambridge: Cambridge University Press.

Kyŏngbuk yŏn'gam [Kyŏngbuk Yearbook]. 1948. Taegu: Yŏngnam ilbosa.

Lange, Matthew K. 2003. "Embedding the Colonial State: A ComparativeHistorical Analysis of State Building and Broad-Based Development in Mauritius.” Social Science History 27: 397-423.

. 2004. "British Colonial Legacies and Political Development." World Development 32: 905-22. 
Lauterback, Richard E. 1947. Danger From the East. New York and London: Harper and Brothers Publishers.

Maeil sinbo [Daily News]. 1945-46. Seoul: Maeil sinbosa.

Mamdani, Mahmood. 1996. Citizen and Subject: Contemporary Africa and the Legacy of Late Colonialism. Princeton, NJ: Princeton University Press.

2. 2003. "From Conquest to Consent as the Basis of State Formation: Reflections on Rwanda.” Pp. 227-70 in The Forging of Nationhood edited by Gyanendra Pandey and Peter Geschiere. New Delhi: Manohar.

Marshall, T. H. [1949] 1992. “Citizenship and Social Class.” Pp. 3-51 in Citizenship and Social Class by T. H. Marshall and Tom Bottomore. London: Pluto Press.

Meade, E. Grant. 1951. American Military Government in Korea. New York: King's Crown Press.

Migdal, Joel S. 1988. Strong Societies and Weak States: State-Society Relations and State Capabilities in the Third World. Princeton, NJ: Princeton University Press.

- 2001. State in Society: Studying How States and Societies Transform and Constitute One Another. Cambridge: Cambridge University Press.

Minjujuŭi minjok chŏnsŏn (Minjŏn). 1946. Chosŏn haebang yŏnbo [Yearbook of Korean Liberation]. Seoul: Munuin sŏgwan.

Morita, Yoshino and Kanako Osada. 1979. Chōsen shūsen no kiroku. Shiryōhen: Nihon tōchi no shūen [A Record of the Termination of War in Korea: The End of Japanese Rule]. Tōkyō: Gannandō Shoten.

Pak, Tu-p'o. 2008. Interview conducted by author in Taegu on May 7.

Peattie, Mark R. 1984. "Introduction." Pp. 3-52 in The Japanese Colonial Empire, 1895-1945 edited by Ramon H. Myers and Mark R. Peattie. Princeton, NJ: Princeton University Press.

Prakash, Gyan. 1995. "Introduction: After Colonialism." Pp. 3-17 in After Colonialism: Imperial Histories and Postcolonial Displacements edited by Gyan Prakash. Princeton, NJ: Princeton University Press.

Robinson, Richard D. 1950. Betrayal of a Nation. Unpublished manuscript. Seoul sinmun [Seoul Daily]. 1946. Seoul: Seoul sinmunsa.

Shin, Gi-wook. 1994. "The Historical Making of Collective Action: The Korean Peasant Uprisings of 1946." American Journal of Sociology 99: 1596-1624.

Sim, Chi-yŏn. 1984. Han'guk hyŏndae chŏngdangron: Han'guk minjudang yŏn'gu [An Analysis of Political Parties in Modern Korea: A Study of the Korean Democratic Party]. Seoul: Ch'angjak kwa pip'yŏngsa.

- 1991. Taegu siwŏl hangjeang yŏn'gu [A Study of the Taegu October Uprisings]. Seoul: Ch'ŏnggye yŏn'guso.

Siwŏl inmin hangjaeng [The October People's Uprising]. 1947. Seoul: Haebangsa.

Smith, Anthony. 1987. The Ethnic Origins of Nations. New York: B. Blackwell.

Sŏ, Chung-sŏk. 1991. Han'guk hyŏndae minjok undong yŏn'gu: Haebang hu minjok kukka kŏnsŏl undong kwa t’ongil chŏnsŏn [A Study of Nationalist Movements in Modern Korea: Movements for the Construction of Nation-State and United Front after Liberation]. Seoul: Yŏksa pip'yŏngsa. 
Steinmetz, George. 2007. The Devil's Handwriting: Precoloniality and the German Colonial State in Qingdao, Samoa, and Southwest Africa. Chicago: University of Chicago Press.

Stoler, Ann Laura and Frederick Cooper. 1997. "Between Metropole and Colony: Rethinking a Research Agenda." Pp. 1-56 in Tensions of Empire: Colonial Cultures in a Bourgeois World edited by Frederick Cooper and Ann Laura Stoler. Berkeley: University of California Press.

Supreme Commander for the Allied Power. 1945. Summation of NonMilitary Activities in Japan and Korea.

United States Armed Forces in Korea. [1946] 1994. “Civil Disturbance." In Haebang chikhu chŏngch'i sahoesa charyŏjip edited by Yong-uk Chŏng. Vol. 6. Seoul: Tarakpang. . 1946. G-2 "Weekly Summary." . 1947 and 1948. "History of the United States Armed Forces in Korea" (HUSAFIK).

Yi, Hye-suk. 1988. "Migunjŏnggi nongmin undong ŭi sŏnggyŏk kwa chŏn'gae kwajŏng" [The Characteristics and Processes of Peasant Movements during the U.S. Occupation Period]. Pp. 229-78 in Haebang chikhu ǔi minjok munje wa sahoe undong edited by Han'guk sahoe sa yŏn'guhoe. Seoul: Munhak kwa chisŏngsa.

Yi, Il-jae. 2008. Interview conducted by author in Taegu on May 22.

Yi, Mok-u. 1965. "Taegu sibil p’oktong sagŏn” [October First Riot in Taegu]. Sedae: 226-45.

Young, Crawford. 1994. The African Colonial State in Comparative Perspective. New Haven and London: Yale University Press.

Young, Robert. 1995. Colonial Desire: Hybridity in Theory, Culture, and Race. New York: Routledge. 